\title{
Arthrobacter psychrochitiniphilus sp. nov., a psychrotrophic bacterium isolated from Antarctica
}

\author{
Correspondence \\ Xiang Xiao \\ xxwfp@public.xm.fj.cn
}

\author{
Fengping Wang, ${ }^{1} \dagger$ Yingbao Gai, ${ }^{1} \dagger$ Mingxia ${ }^{C}{ }^{2}{ }^{2}$ and Xiang Xiao ${ }^{1}$ \\ ${ }^{1}$ Key Laboratory of Marine Biogenetic Resources, Third Institute of Oceanography, State Oceanic \\ Administration, Xiamen, PR China \\ ${ }^{2}$ School of Life Science, Xiamen University, Xiamen, PR China
}

A psychrotrophic Arthrobacter strain, $\mathrm{GP}^{\top}$, was isolated from Adélie penguin guano from Antarctica and characterized. The 16S rRNA gene sequence of the novel strain showed the highest similarity (97.8\%) with that of Arthrobacter psychrolactophilus $\mathrm{B}^{\top}$. The novel strain showed a morphological change from rod to coccus. The growth temperature range of strain GP3 ${ }^{\top}$ was $0-25{ }^{\circ} \mathrm{C}$, with optimal growth at $20{ }^{\circ} \mathrm{C}$. The strain grew over a salinity range of between 0 and $3 \%(\mathrm{w} / \mathrm{v}) \mathrm{NaCl}$ and the optimal $\mathrm{pH}$ for growth was $\mathrm{pH} 6-8$. Strain $\mathrm{GP}^{\top}$ contained anteiso- $C_{15: 0}$ as the major fatty acid. The major menaquinone was MK- $9\left(\mathrm{H}_{2}\right)$. The cell-wall peptidoglycan type was of the $A 3 \alpha$ variant. The DNA G $+C$ content of strain GP3 ${ }^{\top}$ was $58.5 \mathrm{~mol} \%$. Strain GP3 ${ }^{\top}$ was able to hydrolyse chitin, Tween 80 , starch, cellulose and lactose, but not gelatin, lecithin or urea. In addition to these physiological characteristics, DNA-DNA hybridization studies clearly differentiated strain $\mathrm{GP}^{\top}$ from $A$. psychrolactophilus. The combined results of phylogenetic, physiological and chemotaxonomic studies indicated that strain GP3 ${ }^{\top}$ represents a novel species of the genus Arthrobacter. The name Arthrobacter psychrochitiniphilus sp. nov. (type strain $\mathrm{GP} 3^{\top}=\mathrm{JCM} 13874^{\top}=\mathrm{CGMCC} 1.6355^{\top}$ ) is proposed in recognition of the strain's strong chitin-utilizing ability.
Species of the genus Arthrobacter are Gram-positive actinomycetes with a high DNA G $+\mathrm{C}$ content (Keddie et al., 1986; Jones \& Keddie, 1992; Stackebrandt et al., 1983). The majority of the species of the genus Arthrobacter have been isolated from soil, silt and environments such as sludge, sewage and mat samples (http://www.bacterio.cict.fr/a/arthrobacter.html). Most of the recognized species of the genus are mesophilic. However, psychrophilic members of the genus Arthrobacter have been increasingly isolated from Antarctica and other cold environments. Recently described cold-adapted species of the genus Arthrobacter include Arthrobacter psychrolactophilus (Loveland-Curtze et al., 1999), Arthrobacter flavus (Reddy et al., 2000), Arthrobacter roseus (Reddy et al., 2002), Arthrobacter psychrophenolicus (Margesin et al., 2004) and Arthrobacter ardleyensis (Chen et al., 2005). Cold active enzymes of industrial interest have been isolated and characterized from psychrophilic Arthrobacter species (Mavromatis et al., 2003; Skalova et al., 2005). Psychrophilic species of the genus Arthrobacter are potential sources of economically important cold active enzymes.

†These authors contributed equally to this work.

The GenBank/EMBL/DDBJ accession number for the 16S rRNA gene sequence of Arthrobacter psychrochitiniphilus sp. nov. GP3 ${ }^{T}$ is AJ810896.
In our project involving the isolation of cold-adapted bacteria from various cold environments, several Arthrobacter strains were isolated from Antarctic and deep-sea samples (Chen et al., 2005). In this study, strain $\mathrm{GP}^{\mathrm{T}}$, isolated from penguin guano, is characterized.

Strain GP3 ${ }^{\mathrm{T}}$ was isolated from guano of Antarctic Adélie penguins. The sample was collected during the Nineteenth Chinese Antarctic Research Expedition in 2002 at Ardley Island. As penguin deposits are known to contain numerous chitinolytic bacterial strains (Xiao et al., 2005), we used M9 plus chitin plates to isolate chitinolytic bacterial strains from fresh penguin guano samples. The samples were diluted at a ratio of approximately $1: 5(\mathrm{w} / \mathrm{v})$ in distilled water and $100 \mu \mathrm{l}$ aliquots of the suspension were spread on basic M9 agar plates $\left(1^{-1}\right.$ water; $12.8 \mathrm{~g}$ $\mathrm{Na}_{2} \mathrm{HPO}_{4}$. $7 \mathrm{H}_{2} \mathrm{O}, 3 \mathrm{~g} \mathrm{KH}_{2} \mathrm{PO}_{4}, 0.5 \mathrm{~g} \mathrm{NaCl}, 1 \mathrm{~g} \mathrm{NH} \mathrm{NH}_{4}$ and $1.5 \mathrm{~g}$ agar) containing $1 \%(\mathrm{w} / \mathrm{v})$ colloidal chitin prepared as described previously (Xiao et al., 2005). Plates were incubated for 7-28 days at $10{ }^{\circ} \mathrm{C}$. Colonies were subcultured for purification. Strains were selected on the basis of differences in colony morphology. A yellowish, roundedged, smooth colony type with a large chitin-hydrolysing halo dominated in the isolation plates. A representative strain, designated $\mathrm{GP}^{\mathrm{T}}$, was characterized. Strain $\mathrm{GP} 3^{\mathrm{T}}$ was routinely cultivated and maintained using LuriaBertani (LB) medium ( $1 \%$ tryptone, $0.5 \%$ yeast extract 
and $1 \% \mathrm{NaCl}, \mathrm{pH}$ 7.4) in all further experiments, unless otherwise indicated.

DNA isolation and PCR amplification of the 16S rRNA gene fragment of the novel strain were performed as described previously (Chen et al., 2005). A PCR product of around $1500 \mathrm{bp}$ for the $16 \mathrm{~S}$ rRNA gene was cloned into the pGEM-T vector by using a Rapid Ligation kit with $2 \times$ Rapid Ligation buffer according to the manufacturer's instructions (Promega). The ligation mixture was used to transform competent cells of Escherichia coli XL1 Blue according to the manufacturer's recommendations (Promega). A positive clone was picked for sequencing (Sangon Inc.). The resulting sequence was used to search the NCBI database. Related sequences were aligned using CLUSTAL_X (version 1.83) software. A phylogenetic tree was constructed from a matrix of pairwise genetic distances by using the neighbour-joining and minimum-evolution methods as performed with the MEGA (molecular evolutionary genetics analysis; http://www.megasoftware.net/ index.html) software, version 3.1 (Kumar et al., 2004). A bootstrap analysis (1000 replicates) was used to provide confident estimates for phylogenetic tree topologies. The $16 \mathrm{~S}$ rRNA gene sequence of strain $\mathrm{GP} 3^{\mathrm{T}}$ showed the highest similarity $(97.8 \%)$ with that of $A$. psychrolactophilus $\mathrm{B}^{\mathrm{T}}$. The phylogenetic relationships between strain $\mathrm{GP}^{\mathrm{T}}$ and related reference strains from the genus Arthrobacter are shown in Fig. 1. Strain $\mathrm{GP}^{\mathrm{T}}$ and A. psychrolactophilus clearly clustered very closely in the phylogenetic tree. The type strain of $A$. psychrolactophilus, $\mathrm{B} 7^{\mathrm{T}}$, was therefore included for later comparisons in this study (strain provided by Dr J. E. Brenchley).

Standard methods for morphological, biochemical, and physiological characterization were used as described by Dong \& Cai (2001). Cultures of the strains in the lag, exponential and stationary phases of growth were observed under light microscopy. General utilization of carbon sources was determined by using Biolog GP2 microplates (Biolog Inc.). All commercial kits were used according to the manufacturer's instructions. Tests for the utilization of lactose and chitin as sole carbon sources at a concentration of $0.5 \%(\mathrm{w} / \mathrm{v})$ were performed in $10 \mathrm{ml}$ minimal medium containing $0.1 \%(\mathrm{w} / \mathrm{v})$ yeast extract, $0.01 \%(\mathrm{w} / \mathrm{v}) \mathrm{FePO} 4$ and $3.4 \%(\mathrm{w} / \mathrm{v}) \mathrm{NaCl}$. Colonies of strain $\mathrm{GP}^{\mathrm{T}}$ on $\mathrm{LB}$ plates were yellow and circular with entire margins. The strain showed a typical rod-coccus growth cycle (data not shown). Growth of cultures was monitored by measuring $\mathrm{OD}_{600}$. The temperature range for growth of strain GP3 ${ }^{\mathrm{T}}$ was $0-25{ }^{\circ} \mathrm{C}$. The optimal temperature for growth was $20{ }^{\circ} \mathrm{C}$. The doubling times of cultures when grown at 0,20 and $25{ }^{\circ} \mathrm{C}$ were $18.3,4.5$ and $6.0 \mathrm{~h}$, respectively. The novel strain was able to grow over a salinity range of $0-3 \%(\mathrm{w} / \mathrm{v})$ $\mathrm{NaCl}$. The optimum $\mathrm{pH}$ for growth was between $\mathrm{pH} 6$ and $\mathrm{pH}$ 8. The antibiotic sensitivity of the novel strain was assessed by using antibacterial susceptibility discs (Oxoid). The main biochemical and physiological characteristics of the novel strain are given in the species description and in Table 1.

Cell walls were extracted by the TCA method and purified with trypsin according to Schleifer \& Kandler (1972). The composition and molar ratio of the amino acids of the peptidoglycan was analysed with a Biochrom 20 system (Pharmacia). Isoprenoid quinones were extracted and purified according to Collins et al. (1977). The purified menaquinones were analysed by HPLC-MS (LCQ MAT; Finnigan) as previously described by Nishijima et al. (1997). The APCI ion source used was a mixture consisting of 2-propanol and acetonitrile $(1.25: 1, \mathrm{v} / \mathrm{v})$. The major quinone of strain GP3 ${ }^{\mathrm{T}}$ was MK- $9\left(\mathrm{H}_{2}\right)$. Amino acid analysis showed that the cell-wall peptidoglycan contained lysine as the diagnostic diamino acid, as well as alanine, glutamic acid and threonine. The Ala-Glu-Lys-Thr molar ratio of the cell-wall peptidoglycan was about $3: 1: 1: 1$.

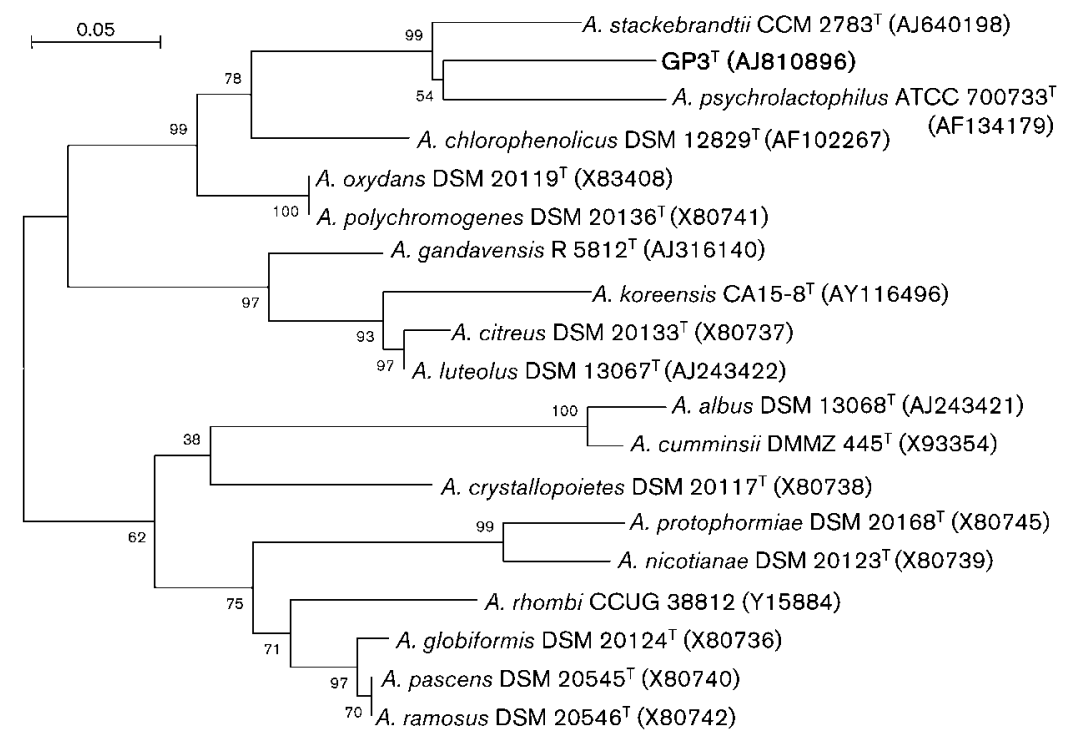

Fig. 1. Phylogenetic tree showing the relationships of strain $\mathrm{GP}^{\top}$ to reference strains of the genus Arthrobacter based on 16S rRNA gene sequences. GenBank accession numbers are given in parentheses. Bar, 5 nucleotide substitutions per 100 nucleotides. 
Table 1. Major phenotypic characteristics that differentiate strain $\mathrm{GP}^{\top}$ and $A$. psychrolactophilus $\mathrm{B}^{\top}$

Strains: $1, \mathrm{GP}^{\mathrm{T}}$; 2, A. psychrolactophilus $\mathrm{B} 7^{\mathrm{T}}$. The optimal $\mathrm{pH}$ for growth for both strains was $\mathrm{pH} 6-8$. Both strains were positive in tests for the production of lipase. + , Positive; - , negative.

\begin{tabular}{|lcc|}
\hline Characteristic & $\mathbf{1}$ & $\mathbf{2}$ \\
\hline Growth range $\left({ }^{\circ} \mathrm{C}\right)$ & $0-25$ & $0-30$ \\
Nitrate reduction & + & - \\
$\mathrm{NH}_{3}$ production & + & - \\
Production of: & & - \\
$\quad$ Chitinase & + & + \\
Gelatinase & - & $+^{*}$ \\
Utilization of: & - & \\
Raffinose & & \\
\hline
\end{tabular}

${ }^{*}$ Data from Loveland-Curtze et al. (1999).

The peptidoglycan of strain $\mathrm{GP}^{\mathrm{T}}$ belonged to the $\mathrm{A} 3 \alpha$ variant (Schleifer \& Kandler, 1972).

Cells for cellular fatty acid analysis were harvested from $24 \mathrm{~h}$ cultures grown at $20{ }^{\circ} \mathrm{C}$ in $\mathrm{LB}$ medium (pH 7.0) with shaking. Fatty acids were extracted and analysed following the instructions of the Microbial Identification System operating manual (MIDI, Inc.). As found for other species of the genus Arthrobacter, strain $\mathrm{GP}^{\mathrm{T}}$ contained anteiso$\mathrm{C}_{15: 0}$ as the major fatty acid. Fatty acids anteiso- $\mathrm{C}_{17: 0 \text {, }}$ iso- $\mathrm{C}_{14: 0}$, iso- $\mathrm{C}_{15: 0}$ and traces of straight-chain saturated fatty acids $\left(\mathrm{C}_{16: 0}\right.$ and $\left.\mathrm{C}_{18: 0}\right)$ were also present (Table 2$)$.

The $\mathrm{G}+\mathrm{C}$ content of the DNA was determined using a HPLC method. DNA was enzymically degraded into nucleosides as described by Tamaoka \& Komagata (1984). The nucleoside mixture obtained was then separated by reverse-phase HPLC using a $\mathrm{C}_{18}$ column (Kromasil ODS, $5 \mu \mathrm{m}, 250 \times 4.6 \mathrm{~mm}$ inner diameter) as described in a previous report (Tamaoka \& Komagata, 1984). The solvent used was $0.05 \mathrm{~mol} \mathrm{NH}_{4} \mathrm{H}_{2} \mathrm{PO}_{4} \mathrm{l}^{-1}$, $\mathrm{pH} 4.0$, containing $7 \%$ acetonitrile. The DNA G $+\mathrm{C} \mathrm{mol} \%$ value was calculated based on the ratio of $\mathrm{G} / \mathrm{G}+\mathrm{T}$ mol\%

Table 2. Fatty acid content

Strains: $1, \mathrm{GP}^{\mathrm{T}} ; 2$, A. psychrolactophilus $\mathrm{B}^{\mathrm{T}}$ (data from LovelandCurtze et al., 1999). tr, $<0.5 \%$.

\begin{tabular}{|c|c|c|}
\hline Fatty acid (\% of total) & 1 & 2 \\
\hline anteiso $\mathrm{C}_{15: 0}$ & 75.6 & $\sim 73$ \\
\hline anteiso $\mathrm{C}_{17: 0}$ & 13.9 & $\sim 13$ \\
\hline isoC $_{14: 0}$ & 1.0 & $\operatorname{tr}$ \\
\hline iso $_{15: 0}$ & 3.2 & $\sim 1.4$ \\
\hline isoC $_{16: 0}$ & $\operatorname{tr}$ & $\sim 8$ \\
\hline $\mathrm{C}_{16: 0}$ & $\operatorname{tr}$ & $\sim 2$ \\
\hline $\mathrm{C}_{18: 0}$ & $\operatorname{tr}$ & $\operatorname{tr}$ \\
\hline
\end{tabular}

according to Mesbah et al. (1989). The DNA G+C content of strain $\mathrm{GP}^{\mathrm{T}}$ was determined to be $58.5 \mathrm{~mol} \%$

Levels of DNA-DNA relatedness between strain $\mathrm{GP}^{\mathrm{T}}$ and A. psychrolactophilus $\mathrm{B}^{\mathrm{T}}$ were determined by DNA-DNA slot-blot hybridization as described by Xiao et al. (2007). The DNA-DNA relatedness value between strain $\mathrm{GP}^{\mathrm{T}}$ and A. psychrolactophilus $\mathrm{B}^{\mathrm{T}}$ was $33.8 \%$, well below the $70 \%$ threshold value for the delineation of genomic species (Wayne et al., 1987).

The results of the 16S rRNA gene sequence and peptidoglycan analyses placed strain $\mathrm{GP}^{\mathrm{T}}$ near $A$. psychrolactophilus $\mathrm{B}^{\mathrm{T}}$. DNA-DNA hybridization, together with physiological and chemotaxonomic studies, clearly indicated that these two strains were different from each other. For example, strain $\mathrm{GP}^{\mathrm{T}}$ had a strong chitin-hydrolysing activity, but $A$. psychrolactophilus $\mathrm{B}^{\mathrm{T}}$ showed no chitinase activity (Table 1). It is concluded that strain $\mathrm{GP}^{\mathrm{T}}$ represents a novel species within the genus Arthrobacter. The name Arthrobacter psychrochitiniphilus sp. nov. is proposed.

\section{Description of Arthrobacter psychrochitiniphilus sp. nov.}

Arthrobacter psychrochitiniphilus (psy.chro.chi.ti.ni.phi'lus. Gr. adj. psychros cold; N.L. n. chitinum chitin; Gr. adj. philos loving; N.L. masc. adj. psychrochitiniphilus a cold, chitin-loving bacterium).

Individual cells show a distinct rod-coccus cycle. Cells are Gram-positive, aerobic, catalase-positive and oxidasenegative with motile rods. Spores or capsules are not seen. Colonies in LB medium at $20{ }^{\circ} \mathrm{C}$ are yellow, circular and convex. Growth occurs at $0-25{ }^{\circ} \mathrm{C}$, the optimal growth temperature is around $20{ }^{\circ} \mathrm{C}$. Grows well at between $0 \%$ and $3 \% \mathrm{NaCl}$. Optimal growth occurs at $\mathrm{pH} 6-8$. Tween 80, starch, cellulose, lactose and chitin are hydrolysed. Gelatin, lecithin and urea are not hydrolysed. Nitrate is reduced and $\mathrm{NH}_{3}$ production is positive. Production of indole and $\mathrm{H}_{2} \mathrm{~S}$ is negative. Sensitive to ampicillin, chloramphenicol, kanamycin, streptomycin and tetracycline. Growth occurs on lactose or chitin as the sole carbon source. The cellular fatty acid pattern is dominated by anteiso- $\mathrm{C}_{15: 0}$. The peptidoglycan type is $\mathrm{A} 3 \alpha$. The major menaquinone is MK- $9\left(\mathrm{H}_{2}\right)$. Biolog tests show that the following compounds are utilized for respiration: dextrin, Tween 40, Tween $80, N$-acetyl-D-glucosamine, L-arabinose, D-arabitol, cellobiose, D-fructose, D-galactose, D-glucose, $\alpha$ D-lactose, lactulose, maltose, maltotriose, D-mannitol, Dmannose, D-melezitose, melibiose, methyl $\beta$-D-galactoside, D-psicose, D-ribose, D-sorbitol, sucrose, D-tagatose, trehalose, turanose, xylitol, D-xylose, acetic acid, $\alpha$-hydroxybutyric acid, $\alpha$-ketovaleric acid, D-lactic acid methyl ester, Llactic acid, L-malic acid, pyruvic acid methyl ester, succinic acid monomethyl ester, propionic acid, pyruvic acid, succinamic acid, succinic acid, $\mathrm{N}$-acetyl-L-glutamic acid, D-alanine, L-alanyl glycine, L-asparagine, L-glutamic acid, glycyl L-glutamic acid, L-serine, putrescine, 2,3butanediol, glycerol, adenosine, inosine, thymidine, uri- 
dine, adenosine $5^{\prime}$-monophosphate, thymidine $5^{\prime}$-monophosphate, uridine $5^{\prime}$-monophosphate, D-glucose 6-phosphate and DL- $\alpha$-glycerol phosphate.

The type strain, GP3 ${ }^{\mathrm{T}}\left(=\mathrm{JCM} 13874^{\mathrm{T}}=\mathrm{CGMCC} 1.6355^{\mathrm{T}}\right)$, was isolated from the guano of Adélie penguins, Antarctica. The DNA G + C content of the type strain is $58.5 \mathrm{~mol} \%$.

\section{Acknowledgements}

We would like to thank the Polar office of the National Oceanic Bureau of China for its support. We are grateful to Dr J. E. Brenchley (Pennsylvania State University) who kindly provided the type strain of Arthrobacter psychrolactophilus. This study was supported by the Natural Science Foundation of China (NSFC No. 40625016), the National Basic Research Program of China (No. 2006CB708200) and the National Infrastructure of Natural Resources for Science and Technology Program of China (No. 2005DKA21209).

\section{References}

Chen, M., Xiao, X., Wang, P., Zeng, X. \& Wang, F. (2005). Arthrobacter ardleyensis sp. nov., isolated from Antarctic lake sediment and deepsea sediment. Arch Microbiol 183, 301-305.

Collins, M. D., Pirouz, T., Goodfellow, M. \& Minnikin, D. E. (1977). Distribution of menaquinones in actinomycetes and corynebacteria. J Gen Microbiol 100, 221-230.

Dong, X. Z. \& Cai, M. Y. (2001). Manual of Systematic Identification of Familiar Bacteria, 1st edn. Beijing, China: Science Publishing Company

Jones, D. \& Keddie, R. M. (1992). The genus Arthrobacter. In The Prokaryotes, vol. 2, pp. 1283-1299. Edited by A. Balows, H. G. Trüper, M. Dworkin, W. Harder \& K. H. Schleifer. Berlin, Heidelberg, New York: Springer.

Keddie, R. M., Collins, D. \& Jones, D. (1986). Genus Arthrobacter. In Bergey's Manual of Systematic Bacteriology, vol. 2, pp. 1261-1266. Edited by P. H. A. Sneath, N. S. Mair, M. E. Sharpe \& J. G. Holt. Baltimore: Williams \& Wilkins.

Kumar, S., Tamura, K. \& Nei, M. (2004). MEGA3: integrated software for Molecular Evolutionary Genetics Analysis and sequence alignment. Brief Bioinform 5, 150-163.

Loveland-Curtze, J., Sheridan, P. P., Gutshall, K. R. \& Brenchley, J. E. (1999). Biochemical and phylogenetic analyses of psychrophilic isolates belonging to the Arthrobacter subgroup and description of Arthrobacter psychrolactophilus, sp. nov. Arch Microbiol 171, 355-363.

Margesin, R., Schumann, P., Spröer, C. \& Gounot, A. M. (2004). Arthrobacter psychrophenolicus sp. nov., isolated from an alpine ice cave. Int J Syst Evol Microbiol 54, 2067-2072.
Mavromatis, K., Lorito, M., Woo, S. L. \& Bouriotis, V. (2003). Mode of action and antifungal properties of two cold-adapted chitinases. Extremophiles 7, 385-390.

Mesbah, M., Premachandran, U. \& Whitman, W. B. (1989). Precise measurement of the $\mathrm{G}+\mathrm{C}$ content of deoxyribonucleic acid by high-performance liquid chromatography. Int J Syst Bacteriol 39, 159-167.

Nishijima, M., Araki-Sakai, M. \& Sano, H. (1997). Identification of isoprenoid quinones by frit-FAB liquid chromatography-mass spectrometry for the chemotaxonomy of microorganisms. J Microbiol Methods 28, 113-122.

Reddy, G. S. N., Aggarwal, R. K., Matsumoto, G. I. \& Shivaji, S. (2000). Arthrobacter flavus sp. nov., a psychrophilic bacterium isolated from a pond in McMurdo Dry Valley, Antarctica. Int J Syst Evol Microbiol 50, 1553-1561.

Reddy, G. S. N., Prakash, J. S. S., Matsumoto, G. I., Stackebrandt, E. \& Shivaji, S. (2002). Arthrobacter roseus sp. nov., a psychrophilic bacterium isolated from an Antarctic cyanobacterial mat sample. Int $J$ Syst Evol Microbiol 52, 1017-1021.

Schleifer, K. H. \& Kandler, O. (1972). Peptidoglycan types of bacterial cell walls and their taxonomic implications. Bacteriol Rev 36, 407-477.

Skalova, T., Dohnalek, J., Spiwok, V., Lipovova, P., Vondrackova, E., Petrokova, H., Duskova, J., Strnad, H., Kralova, B. \& Hasek, J. (2005). Cold-active $\beta$-galactosidase from Arthrobacter sp. C2-2 forms compact $660 \mathrm{kDa}$ hexamers: crystal structure at $1.9 \AA$ resolution. J Mol Biol 353, 282-294.

Stackebrandt, E., Fowler, V. J., Fiedler, F. \& Seiler, H. (1983). Taxonomic studies on Arthrobacter nicotianae and related taxa: description of Arthrobacter uratoxydans sp. nov. and Arthrobacter sulfureus sp. nov. and reclassification of Brevibacterium protophormiae as Arthrobacter protophormiae comb. nov. Syst Appl Microbiol 4, 470-486.

Tamaoka, J. \& Komagata, K. (1984). Determination of DNA base composition by reversed-phase high-performance liquid chromatography. FEMS Microbiol Lett 25, 125-128.

Wayne, L. G., Brenner, D. J., Colwell, R. R., Grimont, P. A. D., Kandler, O., Krichevsky, M. I., Moore, L. H., Moore, W. E. C., Murray, R. G. E. \& other authors (1987). International Committee on Systematic Bacteriology. Report of the ad hoc committee on reconciliation of approaches to bacterial systematics. Int J Syst Bacteriol 37, 463-464.

Xiao, X., Yin, X., Lin, J., Sun, L., You, Z., Wang, P. \& Wang, F. (2005). Chitinase genes in lake sediments of Ardley Island, Antarctica. Appl Environ Microbiol 71, 7904-7909.

Xiao, X., Wang, P., Zeng, X., Bartlett, D. H. \& Wang, F. P. (2007). Shewanella psychrophila sp. nov., Shewanella piezotolerans sp. nov., isolated from west Pacific deep-sea sediment. Int J Syst Evol Microbiol 57, 60-65. 